\title{
The Effect Of Profesional Ethics, Time Budget Pressure, Professional Skepticsm On Audit Quality
}

\author{
Monica Indah Krisdayanti ${ }^{1)}$, Ronny Andesto ${ }^{2}$, Praptiningsih $^{3)}$ \\ Universitas Pembangunan Nasional Veteran Jakarta \\ Email: monica.indah@upnvj.ac.id ${ }^{1)}$
}

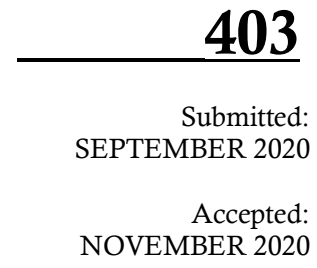

\begin{abstract}
ABSTRAK
Tujuan penelitian ini adalah untuk menguji dan menganalisis pengaruh etika profesi, tekanan anggaran waktu, dan skeptisisme profesional terhadap kualitas. Populasi dalam penelitian ini adalah auditor Badan Pemeriksa Keuangan Republik Indonesia. Pengambilan sampel dilakukan dengan menggunakan metode purposive. Adapun analisis data yang digunakan dalam penelitian ini menggunakan program PLS dengan tingkat signifikansi 5\%. Hasil penelitian ini menunjukkan bahwa (1) etika profesisi berpengaruh signifikan terhadap kualitas audit, (2) tekanan anggaran waktu tidak berpengaruh signifikan terhadap kualitas audit, (3) skeptisisme profesional tidak berpengaruh signifikan terhadap kualitas audit.
\end{abstract}

Kata Kunci: etika profesi; tekanan anggaran waktu; skeptisisme profesional; kualitas audit.

\section{ABSTRACT}

This study aims to examine the effect of professional ethics, time budget pressure, professional skepticism on audit quality. The population in this study was auditors working at BPK Republic of Indonesia. Sampling was carried out using the puruposive method. The data analysis used in this study used the PLS program with a significance level of 5\%. The results of this study indicate that (1) professional ethics has a significant effect on audit quality, (2) time budget pressure has no significant effect on audit quality, (3) professional skepticism has no significant effect on audit quality.

Keywords: Professional Ethics; Time Budget Pressure; Professional Skepticism; Audit Quality

\section{PENDAHULUAN}

Tercapainya pembangunan nasional dapat terlihat dari tata kelola keuangan negara yang dilaksanakan dengan andal dan wajar. Tata kelola penting sebagai pengawasan untuk melaksanakan pengelolaaan keuangan negara. Akuntabilitas sektor publik mengungkapkan transparansi dan memberi informasi kepada masyarakat umum sebagai pemenuhan hak bagi publik. Instansi pemerintah yang memakai keuangan negara diwajibkan menghasilkan laporan keuangan yang dapat diandalkan dan juga memiliki laporan yang berkualitas (Sari \& Lestari, 2018). Harapan pemangku kepentingan dari perusahaan adalah bahwa laporan keuangan dan laporan tahunan adalah relevan dan andal mengenai posisi perusahaan. Untuk mencapai ini, auditor eksternal harus memastikan kualitas audit (Ilechukwu \& Ubaka, 2017). Berdasarkan Standar Pemeriksaan Keuangan Negara tahun 2017, BPK adalah lembaga negara yang bertugas untuk melaksanakan pemeriksaan, pengelolaan dan bertanggung jawab terhadap keuangan negara sesuai dengan UUD Negara RI Tahun 1945, yang menegaskan bahwa untuk memeriksa pengelolaan dan tanggung jawab terhadap keuangan negara diadakan suatu BPK yang bebas dan mandiri.

\section{JIAKES}

Jurnal Ilmiah Akuntansi Kesatuan Vol. 8 No. 3,2020

pg. $403-414$ IBI Kesatuan ISSN $2337-7852$ E-ISSN 2721 - 3048 
Determinants of

Audit Quality

and Auditors

Audit itu sendiri adalah pemeriksaan independen dan pemberian pendapat atas laporan keuangan suatu entitas oleh auditor yang ditunjuk, sesuai dengan penunjukan tersebut dan sesuai dengan kewajiban hukum yang relevan (Abdul-Rahman, Benjamin, \& Olayinka, 2017). Kualitas laporan audit merupakan persyaratan utama agar meningkatkan kredibilitas laporan keuangan bagi pemangku kepentingan. Oleh karena itu kualitas audit merupakan unsur dasar agar meningkatkan kredibilitas dalam laporan keuangan untuk pengguna laporan keuangan tersebut.

Kekhawatiran masyarakat saat ini terkait dengan ketidakpercayaan atas kualitas audit yang disajikan auditor eksternal karena banyak terjadi skandal keuangan terjadi (Ilechukwu \& Ubaka, 2017). Skandal yang terjadi baru-baru ini berdasarkan berita dalam liputan6 yang ditulis oleh (Eagham, 2018), auditor Badan Pemeriksa Keuangan (BPK) yaitu Sigit Yugoharto dituntut 9 tahun hukuman penjara dan membayar denda lima rautus juta rupiah dikarenakan Sigit Yugoharto terbukti menerima suap yaitu motor dengan jenis Harley Davidson Sportster 883 Tahun 2000 dari General Manager PT Jasa Marga Cabang Purbaleunyi yaitu Setia Budi. Selain menerima motor, auditor anggota BPK tersebut juga kedapatan menerima fasilitas karaoke.

Berdasarkan keterangan jaksa, alasan General Manager PT Jasa Marga melakukan suap agar Sigit selaku ketua dari tim PDTT mengubah hasil temuan sementara dari tim pemeriksa BPK atas pemeriksaan dengan tujuan tertentu (PDTT) terhadap pengelolaan pendapatan usaha, pengendalian biaya dan kegiatan investasi pada PT Jasa Marga (Persero) Tbk Cabang Purbaleunyi tahun 2015-2016. Sigit dan timnya mendapatkan dua temuan dalam PDTT yang dikerjakan oleh PT Jasa Marga, yaitu kelebihan pembayaran sebesar Rp 3,1 miliar dan merugikan perusahaan sebesar Rp 4,6 miliar pada tahun 2015 serta pada tahun 2016 diketahui bahwa ada kelebihan pembayaran sebesar Rp 5,9 miliar. Temuan yang didapatkan oleh Sigit dan tim kemudian disampaikan kepada Setiabudi, setelah mengetahui adanya temuan dari tim BPK kemudian Setiabudi memberikan arahan kepada tim BPK agar tidak menginformasikan adanya temuan tersebut dengan memberikan suap kepada tim BPK berupa fasilitas karaoke sebesar lima puluh juta rupiah.

Dari fenomena ini dapat disimpulkan bahwasanya masih terdapat auditor pemerintah yang tidak melaksakan tugasnya seturut dengan ketentuan yang berlaku sehingga dapat merugikan pengguna laporan keuangan dalam mengambil keputusan, untuk itu dalam menjalankan tugasnya auditor perlu perlu menerapkakan etika profesi dengan memperhatikan norma-norma yang ada dalam berprilaku, serta perlu menerapkan sikap sekptisisme profesional untuk mengumpulkan bukti audit sehingga dapat mendeteksi kesalahan dalam laporan keuangan dengan memperhatikan tekanan anggaran waktu yang ditetapkan agar memanfaatkan waktu secara efesien dalam melaksanakan audit, yang membuat laporan audit yang dihasilkan dapat mencerminkan keadaan entitas yang sebenarnya serta dapat diandalkan untuk pengambilan keputusan bagi pengguna laporan keuangan.

Ada banyak faktor-faktor yang dapat mempengaruhi kualitas audit, beberapa dari faktor tersebut adalah etika profesi, kualitas audit dapat dipengaruhi oleh sikap auditor pemerintah dalam menerapkan etika profesi. Profesi auditor selalu dituntut untuk selalu mengikuti kode etik profesional, ada dua prinsip dalam menerapkan etika, yang pertama prinsip imperatif, yaitu prinsip yang mengarahkan pengambilan keputusan berperilaku sesuai dengan persyaratan peraturan etika, dan prinsip utilitarianisme, yaitu penekanan pada memeriksa konsekuensi masing-masing tindakan daripada mengikuti beberapa aturan etika (Haeridistia \& Agustin 2019). Moralitas berfungsi sebagai peraturan konkret atau arahan bagi manusia tentang cara hidup dan bertindak dengan menerapkan perilaku yang baik dan menghindari perilaku buruk; etika merupakan nilai yang terkandung dalam norma moral yang dijadikan acuan dalam berprilaku oleh manusia didalam kehidupan (Meidawati \& Assidiqi 2019). Sesuatu yang dapat membuat beda pekerjaan akuntan publik 
dan pekerjaan lainnya adalah tanggung jawab profesi auditor eksternal untuk melindungi kepentingan masyarakat. Dengan demikian, dapat disimpulkan bahwa tanggung jawab profesi auditor eksternal tidak sebatas pada kepentingan pemberi kerja. Dalam menjalankan tugasnya untuk kepentingan publik, para auditor wajib menerapkan dan mematuhi prinsipprinsip serta kode etik profesi yang mana diatur didalam kode etik profesi (Purwaningsih, 2018).

Penelitian yang dilakukan Purwaningsih (2018) menunjukan etika profesi berpengaruh terhadap kualitas audit dimana adanya penerapan etika profesi auditor eksternal bisa menjalankan tugasnya seturut dengan aturan yang relevan. Audit yang dilaksanakan dengan menerapkan kode etik dapat meningkatkan kualitas audit diakarenakan kode etik adalah sarana publik untuk melakukan penilaian terhadap dari jasa yang diberikan. Hasil berbeda ditunjukan oleh Prasetyawati, Kusdiasmo, \& Dewi (2018) yang menunjukan bahwa etika profesi tidak memiliki pengaruh terhadap kualitas audit. Dikarenakan saat dilakukan pemeriksaan, auditor eksternal kurang memiliki kepercayaan diri atas suatu keadaan yang sulit, sehingga laporan audit yang berkualitas tidak bisa ditentukan dari rasa kepercayaan diri auditor sebagai penerapan dari etika profesi.

Faktor berikutnya yang memiliki pengaruh dengan kualitas audit adalah tekanan anggaran waktu. Kecukupan waktu untuk menyelesaikan tugas diperlukan oleh auditor agar mendapatkan audit yang memiliki kualitas tinggi, terbatasnya waktu audit membuat tantangan bagi para auditor dengan adanya tuntutan yaitu menghasilkan laporan berkualitas. Anggaran waktu dibutuhkan untuk mengukur efektifitas kinerja yang dilakukan auditor (Purwaningsih 2018).

Dalam penelitian Meidawati \& Assidiqi (2019) tekanan anggaran waktu memiliki kontribusi positif terhadap kualitas audit yang disebabkan bahwa tekanan anggaran waktu yang dihadapi oleh auditor secara signifikan mempengaruhi kualitas audit. Tekanan anggaran waktu terkait oleh batasan waktu yang ada selama penugasan karena waktu yang terbatas. Dengan kendala tersebut, seorang auditor termotivasi untuk menyelesaikan pekerjaannya dengan menggunakan waktu seefisien mungkin agar audit yang dihasuilkan berkualitas. Hasil yang berbeda ditunjukan dalam penelitian Purwaningsih (2018) tekanan anggaran waktu audit tidak bepengaruh terhadap kualitas audit, karna ketat atau longgarnya waktu yang diberikan didalam penugasan audit, tidak memiliki pengaruh terhadap kualitas audit. Dikarenakan saat melakukan pekerjaannya auditor selalu menerapkan keahlian dan kompetensi yang memadai. Maka berapapun rentang waktu yang ditetapakan, tugas auditor akan terselesaikan dengan baik dengan menerapkan kompetensi yang ada pada auditor.

Kemudian faktor berikutnya yang berepengaruh terhadap kualitas audit adalah skeptisisme profesional. Standar pemeriksaan keuangan negara (SPKN) menjelaskan dimana untuk melaksanakan pemeriksaan dan menyusun laporan hasil pemeriksaan, auditor mampu menerapkan keahliannya secara professional. Penjelasan tersebut mewajibkan pemeriksa agar menjalankan audit dengan profesional, keahlian profesional tersebut menharuskan pemeriksa agar menggunakan skeptisisme profesional, yang merupakan perilaku kritis untuk menjalankan evaluasi dan memiliki pikiran dimana suatu bukti audit dipertanyakan. Jika auditor skeptis maka kemungkinan adanya salah saji dalam melaksanakan pemeriksaan terminimalisir (Ningsih \& Nadirsyah, 2017). Hasil penelitian dari Ningsih \& Nadirsyah (2017) menunjukan sikap skeptisisme auditor memiliki pengaruh terhadap kualitas audit, dikarenakan dengan auditor yang menerapkan skeptisisme profesionalnya maka akan semakin hati-hati serta waspada untuk mengumpulkan temuan pemeriksaan agar audit yang dihasilkan memiliki kualitas yang baik. Sikap skeptisisme profesional pemeriksa ditunjukan dengan menaikan tingkat kewaspadaan pemeriksa untuk mengevaluasi bukti yang didasarkan perasaan ragu dan keingintahuan sebagai dukungan agar menjamin kualitas audit yang dihasilkan. Sikap
Determinants of Audit Quality and Auditors

405 
Determinants of Audit Quality and Auditors skeptisisme auditor yang rendah membuat auditor kurang peka untuk mendeteksi kecurangan yang ada baik secara nyata maupun yang berupa potensi. Skeptisisme profesional yang dimiliki auditor diharapkan memberi cerminan terhadap keahlian profesional pada diri auditor, dimana akan mempengaruhi ketepatan opini yang diberikan. Sebelum mengambil suatu keputusan, auditor yang menerapkan skeptisisme profesionalnya akan melakukan pertimbangan atas informas pendukung yang berkaitan. Hasil penelitian yang dilakukan Ningsih \& Nadirsyah (2017) berbeda dengan hasil penelitian Nandari \& Latrini (2015) menunjukan bahwa sikap skeptisisme auditor tidak memilki pengaruh yang signifikan terhadap kualitas audit.

Kontribusi penelitian ini terdapat di sampel penelitian. Penelitian yang telah dilakukan oleh Meidawati \& Assidiqi (2019) menggunakan sampel penelitian pada Kantor Akuntan Publik (KAP) di Semarang, berbeda dalam penelitian ini menggunakan sample pada Badan Pemeriksa Keuangan (BPK) di kantor pusat. Selain itu, dalam penelitian Meidawati \& Assidiqi (2019) memberikan saran kepada peneliti selanjutnya agar menguji variabel lainnya yang dapat mempengaruhi kualitas audit, dalam penelitian ini menambahkan varabel skeptisisme auditor sebagai variabel baru. Rumusan masalah dalam studi ini apakah Etika Profesi, Tekanan, Anggaran Waktu dan Skeptisisme Profesional berpengaruh signifikan terhadap Kualitas Audit. Tujuan dari studi ini adalah guna membuktikan pengaruh antara Etika Profesi, Tekanan, Anggaran Waktu dan Skeptisisme Profesional berpengaruh signifikan terhadap Kualitas Audit.

Pengembangan Hipotesis

Etika profesi adalah pedoman yang digunakan sebagai landasan untuk berprilaku dengan hal tersebut maka akan meningkatkan kepercayaan publik atas kualitas pemeriksaan yang dihasilkan auditor (Ningsih \& Nadirsyah 2017). Pemeriksaan yang dilaksanakan dengan menerapkan etika profesi meningkatkan kualitas audit yang dilakukan karena kode etik adalah sarana untuk publik dalam melakukan penilaian mutu dari pemeriksaan yang dilakukan (Purwaningsih, 2018). H1 : Etika Profesi berpengaruh signifikan terhadap Kualitas Audit.

Shintya, Nuryatno, \& Oktaviani (2016) menyatakan bahwa tekanan anggaran waktu merupakan kondisi di mana pemeriksa dituntut agar menerapkan efisiensi pada anggaran waktu yang dirancang atau untuk menerapkan tenggat waktu anggaran waktu yang ketat. Tekanan anggaran waktu berpengaruh terhadap kualitas audit dikarenakan adanya tekanan anggaran waktu dalam menyelesaikan audit membuat seorang auditor termotivasi untuk menyelesaikan pekerjaannya dengan menggunakan waktu seefisien mungkin untuk menghasilkan kualitas audit yang baik. (Meidawati \& Assidiqi, 2019). H2 : Tekanan Anggaran Waktu berpangurh singifikan terhadap Kualitas Audit

Menurut (SPKN, 2017) skeptisisme profesional berarti pemeriksa tidak menganggap bahwa pihak yang bertanggung jawab adalah tidak jujur, tetapi juga tidak menganggap bahwa kejujuran pihak yang bertanggung jawab tidak dipertanyakan lagi. Skeptisisme profesional berpengaruh terhadap kualitas audit, dimana auditor yang menunjukan sikap skeptisisme profesionalnya dengan berpikir skeptis dengan meningkatkan kewaspadaan pemeriksa untuk melakukan evaluasi bukti yang didasari keraguan atau keingintahuan untuk mendukung terjaminnya kualitas audit yang dihasilkan. (Purwaningsih, 2018). H3 : Skeptisisme Profesional berpangurh singifikan terhadap Kualitas Audit

\section{METODOLOGI PENELITIAN}

\section{Populasi dan Sample}

Sampel studi ini merupakan auditor yang bekerja pada BPK Republik Indonesia. Pengambilan sampel pada studi ini menggunakan kuesioner dengan teknik purposive sampling method dimana sample adalah auditor yang memiliki kriteria yang telah 
ditetapkan yaitu auditor yang memiliki pengalaman kerja minimal lima tahun, serta memiliki latar belakang pendidikan akuntansi.

\section{Pengukuran Variable}

Kualitas Audit Indikator dan alat ukur yang digunakan pada variabel ini berdasarkan (SPKN, 2017) meliputi kode etik, pengendalian mutu, manajemen \& keahlian tim pemeriksa, risiko pemeriksaan, materialitas dalam pemeriksaan keuangan Negara, komunikasi pemeriksaan, dokumentasi pemeriksaan dengan menggunakan skala likert. Skala likert digunakan untuk mengukur suatu sikap berdasarkan cara menyatakan setuju atau tidak setuju terhadap subjek, objek atau kejadian tertentu (Suprapto, 2017, hlm 135). Etika Profesi. Indikator dan alat ukur yang digunakan pada variabel ini berdasarkan (Hayes et al., 2017: 84) meliputi integritas, objektivitas, kompetensi dan sikap kehati-hatian secara professional, kerahasiaan, perilaku profesional dengan menggunakan skala likert. Tekanan Anggaran Waktu. Indikator dan alat ukur yang digunakan pada variabel ini meliputi efisiensi terhadap anggaran waktu, pembatasan waktu yang ketat dalam anggaran, menyelesaikan audit tepat waktu,tingkat pemenuhan pencapaian anggaran waktu auditor dengan menggunakan skala likert.Skeptisisme Profesional. Indikator dan alat ukur yang digunakan pada variabel ini berdasarkan (Messier et al., 2017: 753) meliputi questioning mind, suspensiono of judgment, search foreknowledge, interpersonal understanding, autonomy, selfesteem dengan menggunakan skala likert.

Teknik analisis data yang digunakan dalam penelitian ini dibantu oleh program Partial Least Square (PLS) version 3.3.0. Outer model (uji validitas dan uji realiabilitas) dilakukan terlebih dahulu sebelum melakukan pengolahan data, guna mengetahui akurasi dan konsisten data yang dikumpulkan dari para pengguna pengukuran. Jika outer model sudah dilakukan, kemudian menggunakan inner model (uji adjusted dan Q-square), uji statistik deskrptif dan uji hipotesis.

\section{HASIL DAN PEMBAHASAN}

Uji kualitas data digunakan untuk mengetahui apakah kuesioner yang digunakan dikatakan sah atau valid, apabila jawaban dari kuesioner yang diukur tersebut dijawab yang mampu menghasilkan pernyataan dalam bentuk konsisten atau reliable.

\section{Model Pengukuran (Outer Model)}

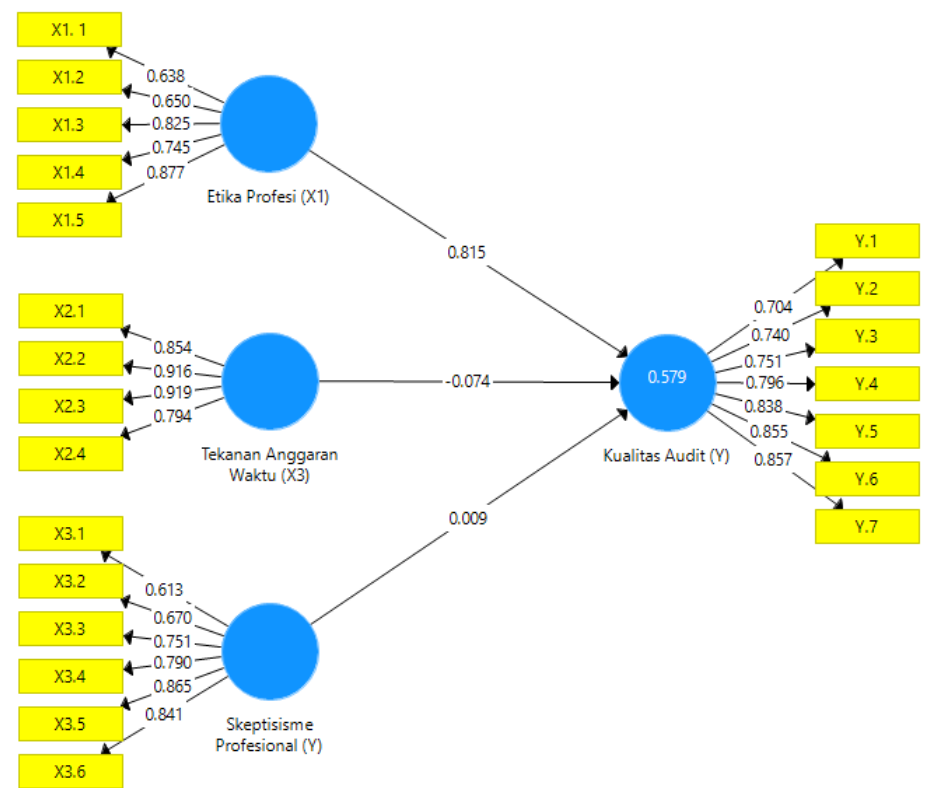

Sumber: Hasil Output SmartPLS 3.3.0
Determinants of Audit Quality and Auditors 
Determinants of Audit Quality and Auditors

Model pengukuran dengan menggunakan validitas konvergen dinilai dengan korelasi antar item score atau component score dengan konstruk skor yang dihitung menggunakan PLS. Ukuran refleksi individual dapat dikatakan tinggi apabila dapat berkorelasi lebih dari 0,70 dengan konstruk yang akan diukur dan apabila nilai loading faktor lebih kecil dari 0,70 maka indikator tersebut dinyatakan tidak valid dan dikeluarkan dari konstruk (Ghozali, 2015, hlm. 74). Hasil uji validitas diagram jalur awal dengan SmartPLS 3.3.0 menunjukkan diagram jalur yang terbentuk sebagaimana Gambar 1. Berdasarkan diagram jalur outer loading factor pada gambar 1 diatas, indikator-indikator yang nilai loading nya kurang dari 0,50 akan didrop dari analisis

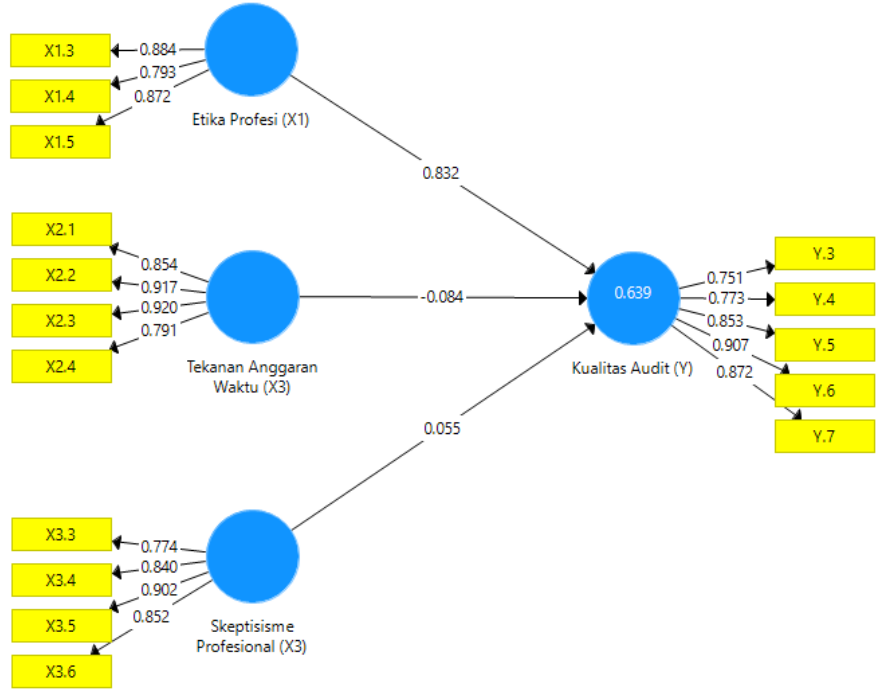

Sumber: Hasil Output SmartPLS 3.3.0

Gambar 2. Outer Model 2

Dari Gambar 2 menunjukan bahwa semua outer loading diatas 0,70 dan nilai outer loading terkecil adalah 0,751 untuk indikator Y.3 sehingga dinyatakan valid atau telah memenuhi convergent validity, namun untuk indikator X1.1, X1.2 X3.1, X3.2, Y1.1, dan Y2.2 memiliki nilai outer loading dibawah $<0.70$ sehingga indikator tersebut dikeluarkan dari model dan tidak signifikan (Ghozali \& Latan, 2015, hlm.62). Variabel etika profesi memuat 5 pernyataan, tetapi dari pernyataan tersebut terdapat 3 pernyataan yang memenuhi convergent validity, sedangkan 2 pernyataan lainnya tidak memenuhi convergent validity. Variabel tekanan anggaran waktu memuat 4 pernyataan, semua pernyataan memenuhi convergent validity. Variabel skeptisisme profesional memuat 6 pernyataan, hanya 2 pernyataan yang tidak memenuhi convergent validity, sedangkan 4 pernyataan lainnya memenuhi convergent validity. Pada variabel dependen yaitu kualitas audit terdapat 7 pernyataan, 5 pernyataan yang memenuhi memenuhi convergent validity, sedangkan 2 pernyataan lainnya tidak memenuhi convergent validity.

Tabel 1. Fornell-Lacker Criterium.

\begin{tabular}{lllll}
\hline \multicolumn{1}{c}{ Konstruk } & $\begin{array}{c}\text { Etika } \\
\text { Profesi } \\
(\mathbf{X} 1)\end{array}$ & $\begin{array}{c}\text { Kualitas } \\
\text { Audit (Y) }\end{array}$ & $\begin{array}{c}\text { Skeptisisme } \\
\text { Profesional } \\
\text { (X3) }\end{array}$ & $\begin{array}{c}\text { Tekanan } \\
\text { Anggaran } \\
\text { Waktu (X3) }\end{array}$ \\
\hline Etika Profesi (X1) & 0.851 & & & \\
\hline Kualitas Audit (Y) & 0.797 & 0.833 & & \\
\hline Skeptisisme Profesional & 0.621 & 0.519 & 0.843 & \\
\hline Tekanan Anggaran Waktu & 0.817 & 0.630 & 0.632 & 0.872 \\
\hline
\end{tabular}

Sumber: Data diolah 
Pada tabel 1 menunjukkan bahwa discriminant validity melalui tabel FornellLacker Criterium memiliki nilai diatas 0,60 pada masing-masing variabel. Variabel Etika Profesi (X1) memiliki nilai sebesar 0,851. Variabel Tekanan Anggaran Waktu (X2) memiliki nilai sebesar 0,872. Variabel Skeptisisme Profesional (X3) memiliki nilai sebesar 0,843. Variabel dependen Kualitas Audit memiliki nilai sebesar 0,833. Dapat disimpulkan bahwa semua konstruk etika profesi, tekanan anggaran waktu, skeptisisme profesional dan kualitas audit adalah valid.

Berdasarkan discriminant validity diatas, maka dapat dilihat pula dengan metode lain yakni nilai dari squareroot of average variance extracted (AVE), pada model ini dikatakan baik jika memiliki nilai AVE yang masing-masing konstruk diatas 0,50 (Ghozali \& Latan, 2015, hlm.75). berikut ini adalah nilai AVE pada penelitian ini:

Tabel 2. Avarege Variance Distracted (AVE).

\begin{tabular}{ll}
\hline Konstruk & Rata-rata Varian Diekstrak (AVE) \\
\hline Etika Profesi (X1) & 0.724 \\
\hline Kualitas Audit (Y) & 0.694 \\
\hline Skeptisisme Profesional (X3) & 0.711 \\
\hline Tekanan Anggaran Waktu (X2) & 0.761 \\
\hline Sumber: Data diolah
\end{tabular}

Berdasarkan tabel 2 menunjukkan bahwa nilai AVE bernilai diatas 0,50 untuk seluruh variabel yang terdapat pada model penelitian ini. Nilai terendah AVE pada penelitian ini sebesar 0,694 pada Kualitas Audit (Y). Dengan demikian, variabel etika profesi, tekanan anggaran waktu, skeptisisme profesional dan kualitas audit adalah valid, karena nilai dari masing-masing variabel tersebut diatas 0,50.

Hasil output software SmartPLS 3.0 menunjukkan nilai Composite Reability dan Cronbach's Alpha dimana dituliskan dalam Ghozali \& Latan (2015, hlm.75) bahwa nilai Composite Reability dan Cronbach's Alpha harus bernilai lebih besar 0,7 tetapi untuk penelitian awal nilai 0,6-0,7 masih dapat diterima. Adapun masing-masing konstruk dalam penelitian ini sebagai berikut:

Tabel 3. Composite Reliability

\begin{tabular}{lc}
\hline Konstruk & Reliabilitas Komposit \\
\hline Etika Profesi (X1) & 0.887 \\
\hline Kualitas Audit (Y) & 0.919 \\
\hline Skeptisisme Profesional (X3) & 0.908 \\
\hline Tekanan Anggaran Waktu (X2) & 0.927 \\
\hline
\end{tabular}

Sumber: Data diolah

Pada table 3 menunjukan bahwa untuk semua konstruk memiliki nilai composite reliability diatas 0,70 yang artinya semua konstruk pada model penelitian ini memenuhi kriteria. Nilai terendah composite reability pada penelitian ini sebesar 0,887 untuk variabel etika profesi. Maka disimpulkan bahwa, semua variabel memiliki reliabilitas yang baik terhadap masing-masing konstruknya. Uji reliabilitas juga dapat diperkuat dengan Cronbach's Alpha, dengan hasil output sebagai berikut:

Tabel 4. Cronbach's Alpha

\begin{tabular}{lc}
\hline Konstruk & Cronbach's Alpha \\
\hline Etika Profesi (X1) & 0.808 \\
\hline Kualitas Audit (Y) & 0.889 \\
\hline Skeptisisme Profesional (X3) & 0.864 \\
\hline Tekanan Anggaran Waktu (X2) & 0.894 \\
\hline
\end{tabular}

Determinants of Audit Quality and Auditors

409 
Determinants of Audit Quality and Auditors

Berdasarkan table 4 menunjukkan bahwa nilai terendah dari Cronbach's Alpha pada penelitian ini yaitu sebesar 0,808 pada variabel etika profesi. Berarti bahwa semua variabel memiliki reliabilitas yang sangat baik terhadap masing-masing konstruknya.

\section{Model Struktural (Inner Model)}

Model struktural (inner model) dilakukan dengan melihat nilai dari $R$-Square, Q-Square dan nilai koefisien jalur (Path Coefficient). Pengujian $R$-Square yang digunakan untuk variabel dependen memperoleh hasil output software SmartPLS 3.3.0 sebagai berikut:

Tabel 5. Adjusted R-Square.

\begin{tabular}{lc}
\hline Konstruk & Adjusted $R$-Square \\
\hline Kualitas Audit $(\mathrm{Y})$ & 0.617 \\
\hline Sumber: Data diolah &
\end{tabular}

Dari table 5 diketahui bahwa hasil $R$-Square $\left(\mathrm{R}^{2}\right)$ yang dilihat dari Adjusted $R$-Square Kualitas Audit adalah sebesar 0,652 dengan demikian dapat diartikan bahwa variabel independen yakni etika profesi, tekanan anggaran waktu, dan skeptisisme professional dapat menjelaskan variabel dependen yaitu Kualitas Audit sebesar 61,7\% dan sisanya sebesar 38,3\% dapat dijelaskan oleh faktor-faktor lain diluar penelitian ini.

Q-square dapat digunakan untuk menilai seberapa baik observasi yang dihasilkan oleh model dan dapat mengestimasi parameternya. Nilai Q-Square harus lebih besar dari 0(nol), yang artinya bahwa menunjukkan model tersebut mempunyai nilai predictive relevance, sedangkan apabila nilai Q-Square dibawah 0(nol) maka model tersebut kurang memiliki predictive relevance (Ghozali \& Latan, 2015, hlm.79).

Perhitungan Q-Square dilakukan dengan menggunakai rumus:

Keterangan:

$$
\text { " } \mathrm{Q}^{2}=1-\left(1-\mathrm{R} 1^{2}\right)\left(1-\mathrm{R} 2^{2}\right) \ldots\left(1-\mathrm{Rp}^{2}\right) "
$$

$\mathrm{Q}^{2}$ mempunyai nilai rentangi $<\mathrm{Q}^{2}<1$ yakni, jika semakin mendekatii1 berarti memiliki model yang semakinibaik.

$\mathrm{R}_{1}^{2}, \mathrm{R}_{2}^{2} \ldots \mathrm{R}_{\mathrm{P}}^{2}$ adalah $R$-square variabel endogen pada model persamaan.

$\mathrm{Q}^{2}=1-\left(1-\mathrm{R} 1^{2}\right)=1-(1-0,639)=1-0,36=0,639$

Hasil $\mathrm{Q}^{2}$ diatas sebesar 0,639 . Hasil ini sesuai dengan kententuan besaran $\mathrm{Q}^{2}$ yakni dengan nilai rentang $0<0,639<1$. Artinya, apabila semakin mendekati 1 berarti memiliki model yang semakin baik.

\section{Koefisien Jalur (Path Coefficients)}

Hasil pengolahan data untuk model struktural pada koefisien jalur menunjukkan sebagai berikut:

Tabel 6. Nilai Hasil Koefesien Analisis Jalur

\begin{tabular}{|c|c|c|c|c|c|}
\hline Konstruk & $\begin{array}{l}\text { Sample } \\
\text { Asli (O) }\end{array}$ & $\begin{array}{l}\text { Rata-rata } \\
\text { Sample (M) }\end{array}$ & $\begin{array}{l}\text { Standar } \\
\text { Deviasi } \\
\text { (STDEV) }\end{array}$ & $\begin{array}{c}\text { T Statistik } \\
(\mid \text { O/STDEV } \mid)\end{array}$ & P Values \\
\hline $\begin{array}{l}\text { Etika Profesi (X1) } \\
\text { Kualitas Audit (Y) }\end{array}$ & 0.832 & 0.847 & 0.154 & 5.404 & 0.000 \\
\hline $\begin{array}{l}\text { Skeptisisme Profesional } \\
\text { (X3) -> Kualitas Audit } \\
\text { (Y) }\end{array}$ & 0.055 & 0.049 & 0.126 & 0.436 & 0.332 \\
\hline $\begin{array}{l}\text { Tekanan Anggaran } \\
\text { Waktu (X2) }->\text { Kualitas } \\
\text { Audit (Y) }\end{array}$ & -0.084 & -0.086 & 0.140 & 0.598 & 0.275 \\
\hline
\end{tabular}




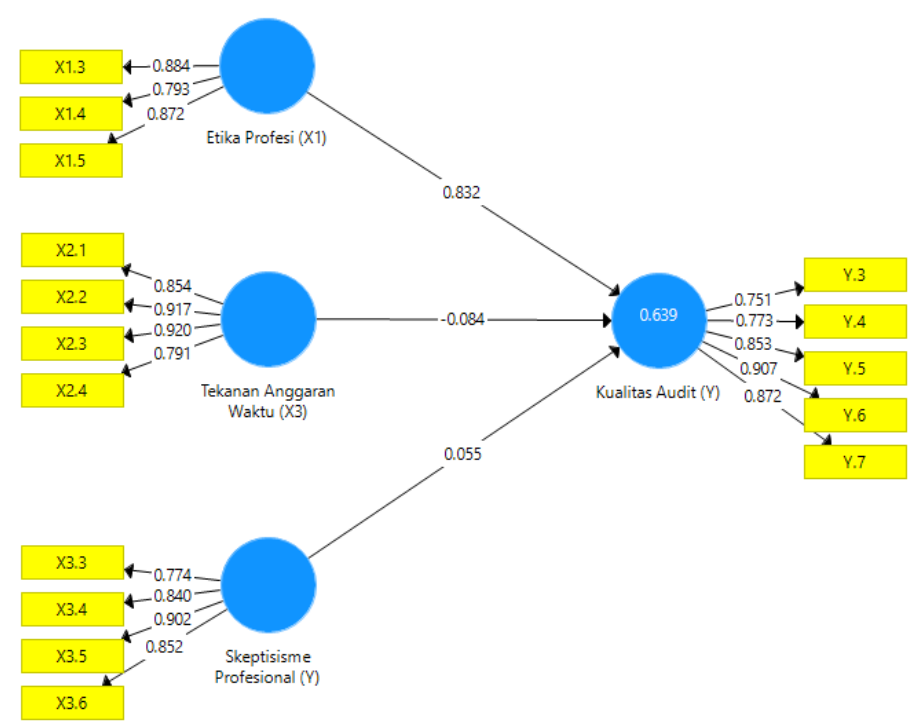

Determinants of Audit Quality and Auditors

Gambar 3. Inner Model

Tabel 7. Interpretasi Hasil Koefesien Jalur

\begin{tabular}{lccccc}
\hline Variabel & Koefisien & Pengaruh & Total \\
\hline X1 terhadap Y & 0.832 & Langsung & 0.832 & Tidak langsung & 0.832 \\
\hline X2 terhadap Y & -0.084 & & -0.084 & & -0.084 \\
\hline X3 terhadap Y & 0.055 & & 0.055 & & 0.055 \\
\hline
\end{tabular}

Sumber: Data diolah

Dari tabel 7 dapat diketahui hubungan antara variabel independen dengan dependen yaitu:

a. Dari tabel diatas dapat diketahui bahwa besarnya hubungan antara variabel etika profesi sebesar 0,832. Hal ini menyatakan bahwa variabel X1 terdapat total hubungan positif terhadap variabel Y sebesar 0,832 .

b. Dari tabel diatas dapat diketahui bahwa besarnya hubungan antara tekanan anggaran waktu sebesar $-0,084$. Hal ini menyatakan bahwa variabel X2 terdapat total hubungan negatif terhadap variabel $Y$ sebesar $-0,084$.

c. Dari tabel diatas dapat diketahui bahwa besarnya hubungan antara variabel skeptisisme professional sebesar 0,055. Hal ini menyatakan bahwa variabel X4 terdapat total hubungan positf terhadap variabel Y sebesar 0,055 .

\section{Uji Hipotesis dan analisis}

Uji $t$ digunakan untuk mengetahui adanya pengaruh signifikan atau tidak antara variabel independen dengan variabel dependen dalam suatu penelitian. Diketahui $t_{\text {tabel }}=$ 1,675 yang diperoleh dari rumus " $\mathrm{df}=\mathrm{n}-\mathrm{k}$ atau $\mathrm{df}=54-4$ dengan tingkat kepercayaan 5\%". Pengambilan keputusan berdasarkan tingkat signifikansi dan membandingkan nilai $t_{\text {hitung }}$ dengan nilai tabel. Jika tingkat signifikansi $<0,05$ maka variabel independen secara parsial berpengaruh signifikan terhadap variabel dependen, dan jika nilai $t_{\text {hitung }}>t_{\text {tabel }}$ maka variabel independen secara parsial berpengaruh signifikan terhadap variabel dependen.

Tabel 8. Hasil Uji t-Statistik.

\begin{tabular}{|c|c|c|}
\hline Konstruk & $\begin{array}{c}\text { t Statistik } \\
(\mid \text { O/STDEV } \mid)\end{array}$ & P Values \\
\hline Etika Profesi (X1) -> Kualitas Audit (Y) & 5.404 & 0.000 \\
\hline $\begin{array}{lll}\text { Skeptisisme Profesional } & \text { (X3) } & -> \\
\text { Kualitas Audit }(Y) & \end{array}$ & 0.436 & 0.332 \\
\hline $\begin{array}{lllll}\text { Tekanan } & \text { Anggaran } & \text { Waktu } & \text { (X2) } & -> \\
\text { Kualitas Audit (Y) } & & & \end{array}$ & 0.598 & 0.275 \\
\hline
\end{tabular}

Sumber: Data diolah 
Determinants of Audit Quality and Auditors
Dari tabel 8 diketahui bahwa hasil pengujian untuk variabel etika profesi (X1) terhadap kualitas audit $(\mathrm{Y})$ memperoleh $\mathrm{t}_{\text {hitung }}>\mathrm{t}_{\text {tabel }}$ yaitu sebesar 5,404 $>1,675$ dan nilai signifikan $0,00<0,05$. Hal ini menunjukkan bahwa Etika Profesi berpengaruh signifikan terhadap Kualitas Audit. Berdasarkan hasil pada tabel diatas menunjukkan bahwa variabel tekanan anggaran waktu (X2) terhadap kualitas audit $(\mathrm{Y})$ memperoleh $t_{\text {hitung }}<t_{\text {tabel }}$ yaitu sebesar $0.598<1,675$ dan signifikan $0.275>0,05$. Sehingga dapat disimpulkan bahwa Tekanan Anggaran Waktu tidak berpengaruh dan tidak signifikan terhadap Kualitas Audit. Berdasarkan hasil pada tabel diatas menunjukkan bahwa skeptisisme profesional (X2) terhadap kualitas audit (Y) memperoleh $t_{\text {hitung }}<t_{\text {tabel }}$ yaitu sebesar $0.436<$ 1,675 dan signifikan $0.332>0,05$. Sehingga dapat disimpulkan bahwa Skeprisisme Profesional tidak berpengaruh dan tidak signifikan terhadap Kualitas audit.

\section{PENUTUP}

Penelitian ini bertujuan untuk membuktikan secara empiris dan menganalisis pengaruh etika profesi, tekanan anggaran waktu, skeptisisme professional terhadap kualitas audit. Setelah melakukan penelitian dengan serangkaian pengujian hipotesis dengan menggunakan Excel dan program Partial Least Square auditor maka dapat ditarik kesimpulan sebagai berikut:

1. Variabel etika profesi secara parsial berpengaruh signifikan terhadap kualitas audit, sehingga dapat dikatakan bahwa etika profesi mempunyai pengaruh signifikan terhadap kualitas audit. Hal ini terjadi karena karena kepatuhan auditor terhadap kode etik dan norma akan tercermin dalam integritas, objektivitas, perilaku professional dalam pengambilan keputusan sehingga menghasilkan audit yang berkualitas.

2. Variabel tekanan anggaran waktu secara parsial tidak berpengaruh dan tidak signifikan terhadap kualitas audit, sehingga dapat dikatakan bahwa skeptisisme profesional tidak memiliki pengaruh dan tidak signifikan kualitas audit. Hal ini dapat terjadi karena dalam menjalankan tugas berapapun alokasi waktu yang ditetapakan, auditor akan menyelesaikan tugasnya dengan baik dengan menerapkan kompetensi yang ada pada auditor.

3. Variabel skeptisisme profesional secara parsial tidak berpengaruh dan tidak signifikan terhadap kualitas audit, sehingga dapat dikatakan bahwa skeptisisme profesional tidak memiliki pengaruh dan tidak signifikan terhadap kualitas audit. Hal ini dikaerenakan saat dilakukan pemeriksaan, auditor eksternal kurang memiliki kepercayaan diri atas suatu keadaan yang sulit, sehingga laporan audit yang berkualitas tidak bisa ditentukan dari rasa kepercayaan diri auditor sebagai skeptisisme profesional

\section{DAFTAR PUSTAKA}

Abdul-Rahman, D. O. A., Benjamin, A. O., \& Olayinka, O. H. (2017). Effect of Audit Fees on Audit Quality: Evidence from Cement Manufacturing Companies in Nigeria. European Journal of Accounting, Auditing and Finance Research, 5(1), 6-17. https://doi.org/2053-4086

Andre, A., Marpaung, A.M. and Mekaniwati, A., 2019. Analisis Implikasi Kebijakan Dividen Terhadap Pertumbuhan Perusahaan Dan Kinerja Saham Studi Kasus Pada Pt Mitra Pinasthika Mustika Tbk Yang Terdaftar Di Bursa Efek Indonesia. Jurnal IImiah Manajemen Kesatuan, 7(1), pp.153-161.

Eagham, L. (2018). Terima Suap Harley Davidson, Auditor BPK Dituntut 9 Tahun Penjara. Retrieved from Liputan6 website: https://www.liputan6.com/news/read/3525230/terima-suap-harley-davidsonauditor-bpk-dituntut-9-tahun-penjara

Ghozali, I., \& Latan, H. (2015). Partial Least Squares Konsep, Teknik dan Aplikasi (2nd Ed). Badan Penerbit Undip. 
Haeridistia, \& Nurlita Agustin. (2019). The effect of independence, professional ethics \& auditor experience on audit quality. International Journal of Scientific and Technology Research, 8(2), 24-27.

Hayes, R., Wallage, P., \& Gortemaker, H. (2017). Principles of Auditing, International Standards on Auditing (Third Edit). Salemba Empat.

Humaeni, A., Muanas, M. and Sudradjat, S., 2019. Peranan Program Yongjin Erp Sebagai Sistem Informasi Akuntansi Pengendalian Persediaan Bahan Baku. Jurnal Ilmiah Akuntansi Kesatuan, 7(1), pp.213-218.

Ilechukwu, \& Ubaka, F. (2017). Effect of Audit Fee on Audit Quality of Listed Firms in Nigeria. International Journal of Trend in Research and Development, 4(5), 319-326. https://doi.org/www.ijtrd.com

Kuntari, Y., Chariri, A., \& Nurdhiana, N. (2017). The Effect of Auditor Ethics, Auditor Experience, Audit Fees and Auditor Motivation on Audit Quality. Sriwijaya International Journal of Dynamic Economics and Business, 1(2), 203-218. https://doi.org/10.29259/sijdeb.v1i2.203-218

Listari, S. and Pardede, R.P., 2017. Pengaruh Fluktuasi Suku Bunga Kredit KURS terhadap Profitabilitas. Jurnal Ilmiah Akuntansi Kesatuan, 5(1), pp.8-14.

Meidawati, N., \& Assidiqi, A. (2019). The influences of audit fees , competence , independence, auditor ethics, and time budget pressure on audit quality. Jurnal Akuntansi Dan Auditing Indonesia, 23(2), 117-128. https://doi.org/https://doi.org/10.20885/jaai.vol23. iss2.art6

Messier, W. F., Glover, S. M., \& Parwitt, D. F. (2017). Auditing \& Assurance Services (a systematic approach) (Tenth edit). Mc Graw Hill education.

Nandari, A., \& Latrini, M. (2015). Pengaruh Sikap Skeptis, Independensi, Penerapan Kode Etik, Dan Akuntabilitas Terhadap Kualitas Audit. E-Jurnal Akuntansi, 10(1), 164-181.

Ningsih, F., \& Nadirsyah. (2017). Pengaruh Independensi, Skeptisme Prodesional Auditor, Penerapan Standar Audit, dan Etika Audit Terhadap Kualitas Audit (Studi pada Auditor BPK RI Perwakilan Provisi Aceh). 2(3).

Prasetyawati, G. I., Kusdiasmo, B., \& Dewi, S. N. (2018). Pengaruh Pengalaman Kerja, Independensi, Kompetensi, Due Profesional Care, Dan Etika Profesi Terhadap Kualitas Audit. ADVANCE, 5(1), 38-47.

Purwaningsih, S. (2018). Pengaruh Skeptisme Profesional, Batasan Waktu Audit, Kode Etik Profesi Akuntan Publik Dan Kompetensi Auditor Terhadap Kualitas Audit (Studi Kasus Pada Kantor Akuntan Publik di Tangerang dan Tangerang Selatan). Jurnal Profita. https://doi.org/10.22441/profita.2018.v11.03.010

Riyadi, M.A. and Rouf, A., 2019. Penerapan Sistem Informasi Accurate Versi 5 terhadap Penyusunan Laporan Keuangan (Studi Kasus Pada CV Percetakan Karya). Jurnal Ilmiah Akuntansi Kesatuan, 7(2), pp.266-277.

Roestiono, H., 2019. Pengaruh Verifikasi Data Nasabah Kredit UMKM dan Nilai yang Diberikan untuk Menghindari Kredit Bermasalah. Jurnal Ilmiah Manajemen Kesatuan, 7(2), pp.232-240.

Roestiono, H., Nurfithriyani, S. and Marlin, T., 2016. Tinjauan Pengaruh Sistem Akuntansi Penggajian Dan Pengupahan Dalam Mendukung Pengendalian Intern Gaji Dan Upah Pada Hotel Salak The Heritage. Jurnal Ilmiah Akuntansi Kesatuan, 4(1), pp.014-020.

Sari, E. N., \& Lestari, S. (2018). Pengaruh Kompetensi Dan Time Budget Pressure Terhadap Kualitas Audit Pada Bpk Ri Perwakilan Provinsi Sumatera Utara. Jurnal Riset \& Akuntansi Keuangan, 6(1), 81-92. https://doi.org/10.17509/jrak.v6i1.11280

Shintya, A., Nuryatno, M., \& \& Oktaviani, A. A. (2016). Pengaruh Kompetensi, Independensi, Dan Tekanan Anggaran Wakt Terhadap Kualitas Audit. Fakultas
Determinants of Audit Quality and Auditors 
Determinants of Audit Quality and Auditors
Ekonomi https://doic

Dan

Bisnis

Universitas

Trisakti, $1-19$.

Suprapto, H. (2017). Metode Penelitian untuk Karya Ilmiah. Gosyen Publishing.

Sutomo, H. and Budiharjo, R., 2019. The Effect of Dividend Policy and Return on Equity on Firm Value. International Journal of Academic Research in Accounting, Finance and Management Sciences, 9(3), pp.211-220.

$\underline{414}$

Vinet, L., \& Zhedanov, A. (2011). Pengaruh Time Budget Pressure, Tenur Audit, dan Rotasi Audit terhadap Kualitas Audit. Journal of Physics A: Mathematical and Theoretical, 44(8), 453-464. https://doi.org/10.1088/1751-8113/44/8/085201

Wibowo, W. and Mekaniwati, A., 2020. Pengaruh Struktur Modal dan Kemampulabaan Terhadap Return Saham Perusahaan Properti dan Real Estate Yang Terdaftar di BEI Tahun 2013-2015. Jurnal Ilmiah Manajemen Kesatuan, 8(1), pp.19-28. 